\title{
Inhibition of pancreatic alpha amylase digestion of potato starch by chlorogenic acid in vitro
}

\author{
Z. Karim, M. Holmes and C. Orfila \\ School of Food Science and Nutrition, University of Leeds, Leeds, LS2 9JT, UK
}

Potatoes are the fourth most important crop in the world and the most consumed vegetable in the UK. Chlorogenic acid (5-caffeoylquinic acid, 5-CQA) is the predominant phenolic acid in potatoes ${ }^{(1)}$ and it has been shown to inhibit the activity of alpha amylase when tested on artificial substrates ${ }^{(2)}$. The aim of this project was to investigate the inhibition of porcine pancreatic alpha amylase by 5-CQA at levels expected in potato tissue and also using potato starch as a substrate. The results could support the hypothesis that potato varieties with high 5-CQA levels would have lower glycaemic effects than those with lower levels.

The inhibitory effects of different concentrations of 5-CQA $\left(0-2 \mathrm{mg} \mathrm{mL}^{-1}\right)$ on the activity of porcine pancreatic $\alpha$ - amylase $(0 \cdot 33$ units $\left.\mathrm{mL}^{-1}\right)$ on potato starch $\left(0.83-6.6 \mathrm{mg} \mathrm{mL}^{-1}\right)$ was examined. 5-CQA was added to the enzyme-substrate mixture at the start of the reaction or was pre-incubated for 10 minutes with the enzyme prior to addition of the substrate. Reducing sugar released was measured using the 3,5-dinitrosalicylic (DNS) colorimetric method at two reaction times (5 and 20 min). Reactions were carried out at $37^{\circ} \mathrm{C}$ in $20 \mathrm{mM}$ sodium phosphate buffer $\mathrm{pH} 6.9$ containing $6.7 \mathrm{mM} \mathrm{NaCl}$. All reactions were carried out in triplicate.

The percent of inhibition for various concentrations of 5-CQA (2, 1.5 and $1 \mathrm{mg} / \mathrm{ml})$ without pre-incubation were $45.69 \%, 25.15 \%$ and $3.47 \%$ respectively after 5 min of enzymatic reaction. Fig. 1 shows that the inhibition was more pronounced at 5 min compared to 20 min reaction time. Pre-incubation of the enzyme with 5-CQA (at $1.5 \mathrm{mg} \mathrm{mL}^{-1}$ ) led to a small but significant decrease in activity, observed at both reaction times $(P<0.05)$.

The mechanism of inhibition was investigated by kinetic analyses. The Hans-Woolf plot (Fig. 2) and kinetic parameters (table below) show that 5-CQA decreased the $\mathrm{V}_{\max }$ and increased the $\mathrm{K}_{\mathrm{m}}$ of pancreatic alpha amylase, indicating a mixed-type inhibition mechanism when using potato starch as a substrate.

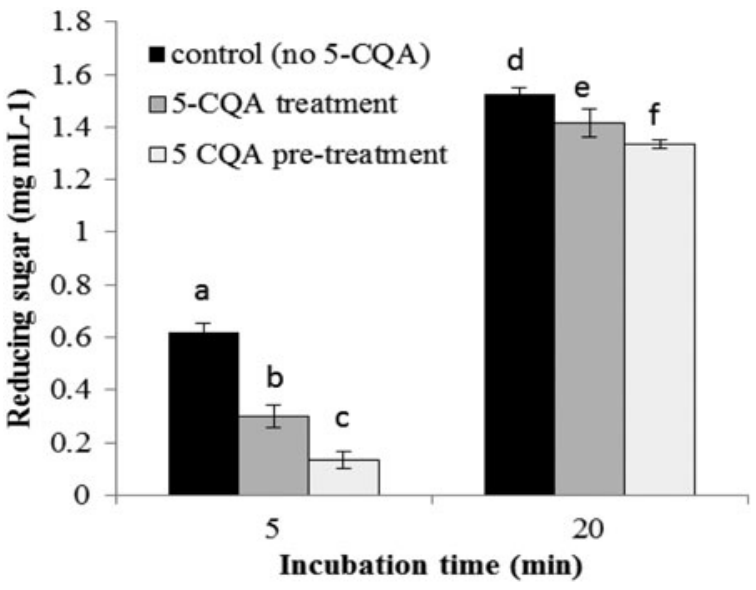

Fig. 1. Effect of 5-CQA (1.5 mg mL-1) on amylase activity; $n=3$, error bars $=\mathrm{SD}, \mathrm{a}, \mathrm{b}, \mathrm{cp}<0.05$ and $\mathrm{d}, \mathrm{e}, \mathrm{f} p<0.05$ at same time point and different treatments

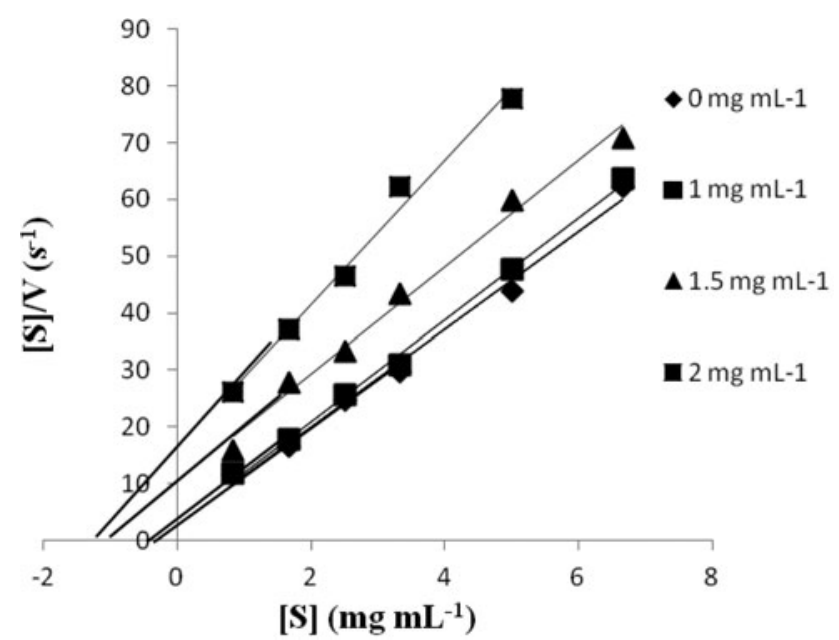

Fig. 2. Hans-Woolf plot at various 5-CQA concentrations.

The results of this study provide evidence that 5-CQA at concentrations found in food could reduce digestibility of potato starch with potential consequences on carbohydrate availability.

\begin{tabular}{lcc}
\hline 5-CQA] $\mathrm{mg} \mathrm{mL}^{-1}$ & $\mathrm{k}_{\mathrm{m}} \mathrm{mg} \mathrm{mL}^{-1}$ & $\mathrm{~V}_{\max } \mathrm{mg} \mathrm{mL}^{-1} \mathrm{sec}^{-1}$ \\
\hline 0 & $0 \cdot 3495$ & $0 \cdot 1165$ \\
1 & 0.4635 & $0 \cdot 1159$ \\
1.5 & 0.8712 & 0.1089 \\
2 & 0.9750 & 0.0755 \\
\hline
\end{tabular}

